2011-01-01

\title{
Effect of Different Drying Temperatures on the Moisture and Phytochemical Constituents of Edible Irish Brown Seaweed
}

\author{
Shilpi Gupta \\ Technological University Dublin, shilpi.19may@gmail.com \\ Sabrina Cox \\ Technological University Dublin, sabrina.cox@tudublin.ie \\ Nissreen Abu-Ghannam \\ Technological University Dublin, nissreen.abughannam@tudublin.ie
}

Follow this and additional works at: https://arrow.tudublin.ie/schfsehart

Part of the Food Processing Commons

\section{Recommended Citation}

Gupta, S., et al., Effect of different drying temperatures on the moisture and phytochemical constituents of edible Irish brown seaweed, LWT - Food Science and Technology (2011), doi:10.1016/j.Iwt.2010.12.022

This Article is brought to you for free and open access by the School of Food Science and Environmental Health at ARROW@TU Dublin. It has been accepted for inclusion in Articles by an authorized administrator of ARROW@TU

Dublin. For more information, please contact

arrow.admin@tudublin.ie, aisling.coyne@tudublin.ie, gerard.connolly@tudublin.ie.

Funder: Irish Government

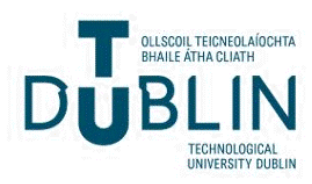




\title{
Effect of different drying temperatures on the moisture and phytochemical constituents of edible Irish brown seaweed
}

\author{
Shilpi Gupta, Sabrina Cox, Nissreen Abu-Ghannam* \\ School of Food Science and Environmental Health, College of Sciences and Health, Dublin Institute of Technology, Cathal Brugha St., Dublin 1, Ireland
}

\section{A R T I C L E I N F O}

\section{Article history:}

Received 11 August 2010

Received in revised form

15 December 2010

Accepted 21 December 2010

\section{Keywords:}

Drying kinetics

Seaweeds

Antioxidant

Total phenol

Arrhenius

\begin{abstract}
A B S T R A C T
The effect of different temperatures on the drying kinetics and the phytochemical constituents of edible Irish brown seaweed, Himanthalia elongata were studied. This kinetic study involved the modelling of the terms of Fick's diffusion equation, for estimation of the diffusion coefficients. The diffusivity coefficient increased from $5.6 \times 10^{-07}$ to $12.2 \times 10^{-07} \mathrm{~m}^{2} / \mathrm{s}$ as the drying temperatures increased with an estimated activation energy of $37.2 \mathrm{~kJ} / \mathrm{mol}$. The experimental data was also fitted to different empirical kinetic models, Newton, Logarithmic and Henderson-Pabis, and the goodness of fit for the different models was evaluated. The effect of drying temperatures on the phytochemical constituents in seaweed was also evaluated. Drying at $25{ }^{\circ} \mathrm{C}$ resulted in $49 \%$ and $51 \%$ reduction in the total phenol and total flavonoid content, respectively, as compared to fresh seaweed. However, the reduction declined as the drying temperatures were increased. The scavenging effect on DPPH radical was also greater for the fresh seaweed as compared to the dried form. An increase in the phytochemical content was seen for higher temperatures $\left(35^{\circ} \mathrm{C}\right.$ and $40^{\circ} \mathrm{C}$ ) when the moisture content reduced by $50 \%$ indicating that this semi-dry state is even more nutritious than the fresh form and could be an interesting starting point for seaweed processing.
\end{abstract}

(c) 2010 Published by Elsevier Ltd.

\section{Introduction}

Seaweeds are a part of staple diet in the orient as they are nutritionally rich materials (Dawczynski, Schubert, \& Jahreis, 2007); but to a much lesser extent in the rest of the world. Beneficial nutrients in seaweeds include vitamins, trace minerals, lipids, amino acids, and antioxidants, all of which form the part of a healthy diet (Athukorala, Kim, \& Jeon, 2006). Numerous studies have reported on the excellent antioxidant capabilities of seaweeds or their extracts (Chandini, Ganesan, \& Bhaskar, 2008; Cox, Abu-Ghannam, \& Gupta, 2009). They live in a harsh environment where they are exposed to a wide range of environmental stress such as light, rapid fluctuations in temperatures, osmotic stress and desiccation. These factors can lead to the formation of free radicals and other strong oxidising agents but seaweeds seldom suffer any serious photodynamic damage. This fact implies that seaweed cells have some protective mechanisms and compounds (Matsukawa et al., 1997).

Being marine in nature seaweeds contain a large amount of water. When fresh, they have $75-85 \%$ water and $15-25 \%$ organic components and minerals. Since seaweeds are perishable in their

\footnotetext{
* Corresponding author. Tel.: +3531402 7570; fax: +3531878 8978.

E-mail addresses: nissreen.abughannam@dit.ie, shilpi.19may@gmail.com (N. Abu-Ghannam)
}

fresh state and could deteriorate within a few days after harvest, drying is an essential step before they can be used in industrial processing. Drying decreases the water activity which ultimately retards the microbial growth, helps to conserve the desirable qualities and reduces the storage volume. However, enzymatic and/or non-enzymatic processes that may occur during drying of the fresh plant tissues may lead to significant changes in the composition of phytochemicals (Capecka, Mareczeek, \& Leja, 2005). Studies by Nicoli, Anese, and Parpinel (1999) showed that the overall antioxidant capacity of certain foods may be enhanced due to improvement in the antioxidant properties of naturally occurring antioxidants and the formation of Maillard reaction products (MRPs).

Seaweeds are generally sun dried by spreading them over a net, a tarpaulin or over coconut leaves on the ground. In Ireland, drying of seaweeds for the production of different grades of seaweed meal is carried out in rotary dryers heated by coal slack fired kilns (http:// www.cleanerproduction.ie). Different drying methods have been found to greatly affect the nutritional composition of the brown seaweed, Sargassum hemiphyllum (Chan, Cheung, \& Ang, 1997). Wong and Cheung (2001) reported that oven-drying was better than freeze-drying for the extractability and quality of proteins isolated from three subtropical brown seaweeds.

Presently seaweeds are sold in health shops and oriental grocery houses in the dried form. The dried seaweeds can be used as a part 


\begin{tabular}{|ll|}
\hline \multicolumn{2}{|l|}{ Nomenclature } \\
$a, c, k$ & Parameters in the models \\
$D_{\mathrm{eff}}$ & Effective diffusivity $\left(\mathrm{m}^{2} / \mathrm{s}\right)$ \\
$D_{\mathrm{o}}$ & Diffusivity at an infinite temperature $\left(\mathrm{m}^{2} / \mathrm{s}\right)$ \\
$E_{\mathrm{a}}$ & Activation energy for moisture diffusion $(\mathrm{kJ} / \mathrm{mol})$ \\
$l$ & Thickness of seaweeds $(\mathrm{m})$ \\
$\mathrm{MR}$ & Moisture ratio \\
$R$ & Gas law constant $(\mathrm{J} /$ molK $)$ \\
$R^{2}$ & Coefficient of determination \\
$\mathrm{RMSE}$ & Root mean square error \\
$\mathrm{SSE}$ & Sum square error \\
$T$ & Drying temperature (Kelvin) \\
$t$ & Drying time (h) \\
$W$ & Moisture content at any time $\left(\mathrm{g} \mathrm{H}_{2} \mathrm{O} / \mathrm{g}\right.$ dry basis $)$ \\
$W_{\mathrm{e}}$ & Equilibrium moisture content $\left(\mathrm{g} \mathrm{H}_{2} \mathrm{O} / \mathrm{g}\right.$ dry basis $)$ \\
$W_{\mathrm{o}}$ & Initial moisture content $\left(\mathrm{g} \mathrm{H}_{2} \mathrm{O} / \mathrm{g} \mathrm{dry} \mathrm{basis}\right)$ \\
$\chi^{2}$ & Chi-square \\
\hline
\end{tabular}

of a raw vegetable salad, as a natural seasoning or as a snack with fresh juice. Some studies are available in literature which study the effect of drying on the nutritional properties of seaweeds but no literature is available studying the effect of drying on the phytochemical constituents such as phenols and flavonoids.

The moisture removal and its dependence on the process variables are expressed in terms of the drying kinetics, being essential for the development of a reliable process model. Empirical equations frequently used to model the drying kinetics of food include: Newton, Page, Henderson-Pabis, Logarithmic, Diffusion approach and others (Simal, Femenía, Garau, \& Roselló, 2005; Vega, Uribe, Lemus, \& Miranda, 2007).

The present work aimed to study the drying kinetics of $H$. elongata at a range of temperatures $\left(25,30,35\right.$ and $\left.40^{\circ} \mathrm{C}\right)$ which are applied in the seaweed industry and to evaluate till what extent drying conditions influence the phytochemical content of the seaweeds. These objectives are justified having in mind that the literature lacks some information on the air-drying kinetics of seaweeds either in terms of empirical models or in terms of diffusivity models. Besides, the change in the phytochemical content due to drying has not been explored.

\section{Materials and methods}

\subsection{Seaweed material}

Brown seaweed H. elongata was supplied from Quality Sea Veg., Co. Donegal, Ireland. Samples were collected in January 2010, washed thoroughly with freshwater to remove epiphytes and salt and stored at $-18{ }^{\circ} \mathrm{C}$ until further analysis.

\subsection{Drying procedure}

Fresh seaweeds were washed and cut manually with stainless steel knife into rectangular samples of approximately $3 \mathrm{~cm} \times$ $0.5 \mathrm{~cm} \times 0.2 \mathrm{~cm}$. Sample $(5 \mathrm{~g})$ was weighed and placed on a flat tray and dried in a hot air oven (Innova 42, Mason Technology, Ireland) at different temperatures of $25,30,35$ and $40^{\circ} \mathrm{C}$. The air velocity was set at $2.0 \pm 0.1 \mathrm{~m} / \mathrm{s}$ as measured with digital anemometer (VWR, Ireland). Samples were withdrawn after every hour until $8 \mathrm{~h}$ and then after every $8 \mathrm{~h}$ for $24 \mathrm{~h}$. The dry solids content was determined by employing control samples using an oven at $105^{\circ} \mathrm{C}$ until constant weight of the sample was attained. The relative humidity was monitored with a data logger Grant 1001.

\subsection{Drying kinetics expressed in terms of empirical models}

The data obtained experimentally for the four different temperatures studied $\left(25,30,35\right.$ and $\left.40^{\circ} \mathrm{C}\right)$ was plotted as a dimensionless variable moisture ratio (MR) versus time:

$\mathrm{MR}=\frac{W-W_{\mathrm{e}}}{W_{0}-W_{\mathrm{e}}}$

where $W$ is the moisture content at any time $t, W_{\mathrm{e}}$ the equilibrium moisture content and $W_{0}$ is the initial moisture content and all expressed as g water/g dry solids. The experimental data (MR Vs time, $t$ ) were fitted to the three different empirical models (Table 1) using STATGRAPHICS Centurion XV (StatPoint Technologies, Inc., Warrenton, VA).

\subsection{Estimation of diffusion coefficient}

The most widely studied theoretical model in thin layer drying of foods is given by the solution of Fick's second law which was used to fit the experimental drying data. For sufficiently long drying times, the Fick's equation (Coulson, Richardson, Backhurst, \& Harker, 1987) can be simplified to Eq. (2):

$\mathrm{MR}=\frac{8}{\pi^{2}}\left(e^{-D_{\text {eff }} t\left(\frac{\pi}{21}\right)^{2}}\right)$

The above equation assumes that the effective diffusivity $\left(D_{\text {eff }}\right)$ is constant and that shrinkage of the sample is negligible. The above equation can be further simplified into a straight line:

$\ln (\mathrm{MR})=\ln \frac{8}{\pi^{2}}-D_{\text {eff }}\left(\frac{\pi}{2 l}\right)^{2} t$

Slope of the above line will give the value of effective diffusivity at different temperatures as:

Slope $=-D_{\text {eff }}\left(\frac{\pi^{2}}{4 l^{2}}\right)$

The effective diffusivity varies with the temperature according to Arrhenius dependence as:

$D_{\text {eff }}=D_{0} \exp \left(-\frac{E_{\mathrm{a}}}{R T}\right)$

where $D_{0}$ is diffusivity at an infinite temperature $\left(\mathrm{m}^{2} / \mathrm{s}\right), E_{\mathrm{a}}$ is the activation energy for moisture diffusion $(\mathrm{kJ} / \mathrm{mol}), T$ is the drying temperature (Kelvin) and $R$ is the gas constant $(8.314 \mathrm{~J} / \mathrm{molK})$.

Upon linearization, the slope indicates the activation energy:

$\ln D_{\text {eff }}=\ln \left(D_{0}\right)+\left(-\frac{E_{\mathrm{a}}}{R}\right) \frac{1}{T}$

\subsection{Effect of drying on the phytochemical analysis}

\subsubsection{Preparation of seaweed extracts}

The extraction of phenolic compounds from $\mathrm{H}$. elongata was carried out with $60 \%$ methanol under nitrogen atmosphere as reported in our previous studies (Gupta, Rajauria, \& Abu-Ghannam, 2010).

Table 1

Empirical models used for the fitting of drying kinetics of $H$. elongata at different temperatures.

\begin{tabular}{ll}
\hline Model name & Equation \\
\hline Newton & $\mathrm{MR}=\exp (-k t)$ \\
Logarithmic & $\mathrm{MR}=a \exp (-k t)+c$ \\
Henderson-Pabis & $\mathrm{MR}=a \exp (-k t)$ \\
\hline
\end{tabular}




\subsubsection{Phytochemical and antioxidant analysis}

2.5.2.1. Total phenolic content (TPC). The TPC in the extract was determined using Folin-Ciocalteau's phenol reagent (Taga, Miller, \& Pratt, 1984). The TPC was expressed as mg gallic acid equivalents (GAE)/100 g dry basis. Fresh weights of each sample were converted into dry weights on the basis of the moisture content.

2.5.2.2. Total flavonoid content (TFC). The TFC was determined by a colourimetric method described by Liu et al. (2009). TFC was expressed as mg quercetin equivalents $(\mathrm{QE}) / 100 \mathrm{~g}$ dry basis.

2.5.2.3. DPPH radical scavenging assay. This assay was carried out as described by Yen and Chen (1995), with some modifications. Analysis were performed in a 96-well microplate with $1: 1$ ratio of $100 \mu \mathrm{l}$ of DPPH solution $(165 \mu \mathrm{M})$ and $100 \mu \mathrm{l}$ of sample. The reaction mixtures were incubated for $30 \mathrm{~min}$ at $25^{\circ} \mathrm{C}$ in dark and absorbance was measured at $517 \mathrm{~nm}$ in a microplate reader (Powerwave, Biotek, VT, USA). The ability to scavenge the DPPH radical was calculated as:

Scavenging capacity $(\%)=\left[1-\left(\frac{A_{\text {sample }}-A_{\text {sampleblank }}}{A_{\text {control }}}\right)\right] \times 100$

where, $A_{\text {control }}$ is the absorbance of DPPH solution without sample, $A_{\text {sample }}$ is the absorbance of DPPH solution plus test sample and $A_{\text {sample blank }}$ is the absorbance of the sample without any DPPH solution. Calculated $\mathrm{EC}_{50}$ values indicate the concentration of sample required to scavenge $50 \%$ DPPH radicals. The lower the $\mathrm{EC}_{50}$ value of the sample, the higher is the antioxidant capacity.

\subsection{Statistical analysis}

All the experiments were carried out in triplicate and replicated at least twice. The goodness of fit of the tested mathematical models to the experimental data was evaluated from the coefficient of determination $\left(R^{2}\right)$, Sum square error (SSE; Eq. (8), root mean square error (RMSE; Eq. (9) and the chi-square ( $\chi^{2}$; Eq. $(10)$ between the predicted and experimental values.

$\mathrm{SSE}=\frac{1}{N} \sum_{i=1}^{N}\left(\mathrm{MR}_{\exp }-\mathrm{MR}_{\mathrm{pred}}\right)^{2}$

$\mathrm{RMSE}=\sqrt{\frac{1}{N} \sum_{i=1}^{N}\left(\mathrm{MR}_{\exp }-\mathrm{MR}_{\mathrm{pred}}\right)^{2}}$

$N^{2}=\frac{\sum_{i=1}^{N}\left(\mathrm{MR}_{\mathrm{exp}, i}-\mathrm{MR}_{\mathrm{pred}, i}\right)^{2}}{N-Z}$

where $\mathrm{MR}_{\exp , i}$ and $\mathrm{MR}_{\mathrm{pred}, i}$ are the experimental and predicted moisture ratio, $N$ is the number of observations and $z$ is the number of constants.

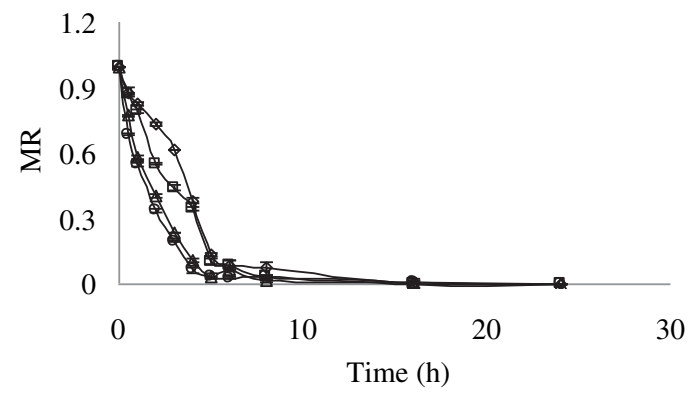

Fig. 1. Experimental drying curves of $H$. elongata at different temperatures $\left(\diamond: 25^{\circ} \mathrm{C}\right.$; $\square: 30{ }^{\circ} \mathrm{C} ; \triangle: 35^{\circ} \mathrm{C} ; 0: 40^{\circ} \mathrm{C}$ ).
Table 2

Estimation of diffusion coefficient for seaweeds drying between 25 and $40{ }^{\circ} \mathrm{C}$

\begin{tabular}{lllll}
\hline & $25{ }^{\circ} \mathrm{C}$ & $30{ }^{\circ} \mathrm{C}$ & $35^{\circ} \mathrm{C}$ & $40{ }^{\circ} \mathrm{C}$ \\
\hline$D_{\mathrm{e}}\left(\mathrm{m}^{2} / \mathrm{s}\right)$ & $5.6 \times 10^{-07}$ & $7.8 \times 10^{-07}$ & $8.5 \times 10^{-07}$ & $12.2 \times 10^{-07}$ \\
$L(\mathrm{~m})$ & 0.002 & 0.002 & 0.002 & 0.002 \\
$R^{2}$ & 0.9262 & 0.9868 & 0.9419 & 0.9822 \\
\hline
\end{tabular}

\section{Results and discussion}

\subsection{Drying curves}

Moisture content of the fresh $H$. elongata was approximately $4.05 \pm 0.05 \mathrm{~kg}$ water $/ \mathrm{kg}$ dry matter. Fig. 1 shows the variation of moisture content as a function of time at the four temperatures studied. All the drying curves show a clear exponential tendency and an increase in the temperature accelerated the drying process. There was significant difference in the moisture content with different drying temperatures $(P<0.05)$. At $25^{\circ} \mathrm{C}$ the drying rate was minimal and approached equilibrium after $8 \mathrm{~h}$ whereas equilibrium at $40{ }^{\circ} \mathrm{C}$ was attained after $5 \mathrm{~h}$, representing 37.5\% reduction in the total drying time. In addition, as the temperature increased, there was an increase in the rate of mass transfer (water) to achieve similar equilibrium moisture content (approximately $0.98 \mathrm{~g}$ water/100 g d.m) (Miranda, Maureira, Rodríguez, \& VegaGálvez, 2009). Seaweeds have a high rate of moisture loss when kept in air and thus have a tendency to loose water quickly. Generally, the seaweed industry employs outdoor drying under atmospheric conditions. Thus, the drying temperatures applied in the present study were low to imitate the air-drying conditions in the industry. Drying was carried out under controlled conditions to achieve optimum drying time which will be short and will not reduce the final quality of the dried product. Moreover, preliminary experiments had shown that drying the seaweeds at temperatures above $50^{\circ} \mathrm{C}$ resulting in colour darkening within $2 \mathrm{~h}$ with a complete loss in the antioxidant properties. The percentage reduction of antioxidants for the samples dried at $50{ }^{\circ} \mathrm{C}$ was $87 \%$.

\subsection{Estimation of diffusion coefficient}

The traditional method for studying the mass transfer at a nonstationary state for the drying of foodstuffs is the Fick's equation (Eq. (2)), from which the effective diffusivity coefficient $\left(D_{\text {eff }}\right)$ is determined. Effective diffusivities of dried seaweeds at different temperatures were obtained from the gradient of the plots of $\mathrm{ln}$ (MR) versus drying time $(t)$ (Eq. (3)) for $25,30,35$ and $40{ }^{\circ} \mathrm{C}$ with slopes of $0.3483 \mathrm{~h}^{-1}, 0.4841 \mathrm{~h}^{-1}, 0.5224 \mathrm{~h}^{-1}$ and $0.6566 \mathrm{~h}^{-1}$, respectively. Table 2 shows the results of the fitting to Eq. (3), which allowed the calculation of the diffusion coefficients, $D_{\text {eff, }}$ at the different temperatures by Eq. (4). The diffusivity increased from $5.6 \times 10^{-07} \mathrm{~m}^{2} / \mathrm{s}$ to $12.2 \times 10^{-07} \mathrm{~m}^{2} / \mathrm{s}$ as the temperature was

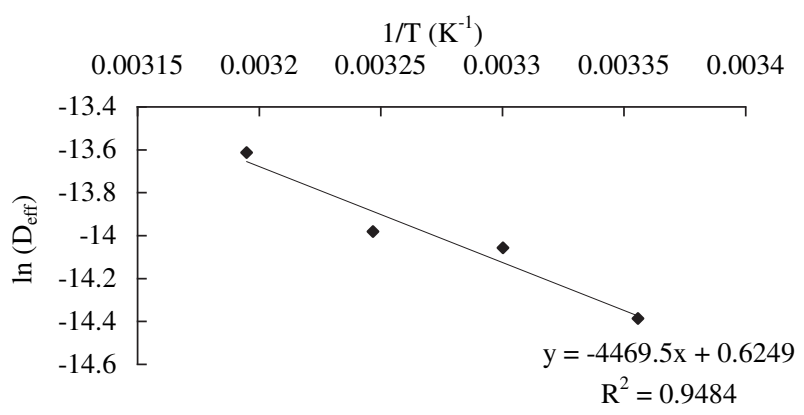

Fig. 2. Variation of effective diffusivity $\left(\mathrm{m}^{2} / \mathrm{s}\right)$ with inverse of temperature 
Table 3

Statistical indices upon modelling the drying of $H$. elongata at a range of temperatures.

\begin{tabular}{llllll}
\hline & Temperature & SSE & RMSE & $\chi^{2}$ & $R^{2}$ \\
\hline Newton & $25{ }^{\circ} \mathrm{C}$ & 0.008 & 0.088 & 0.009 & 0.9434 \\
& $30^{\circ} \mathrm{C}$ & 0.003 & 0.051 & 0.003 & 0.9794 \\
& $35{ }^{\circ} \mathrm{C}$ & 0.0005 & 0.023 & 0.0006 & 0.9794 \\
& $40{ }^{\circ} \mathrm{C}$ & 0.0006 & 0.024 & 0.0006 & 0.9943 \\
& & & & & \\
& $25{ }^{\circ} \mathrm{C}$ & 0.007 & 0.082 & 0.009 & 0.9515 \\
& $30{ }^{\circ} \mathrm{C}$ & 0.002 & 0.046 & 0.003 & 0.9832 \\
& $35{ }^{\circ} \mathrm{C}$ & 0.0005 & 0.023 & 0.0007 & 0.995 \\
& $40{ }^{\circ} \mathrm{C}$ & 0.0005 & 0.023 & 0.0007 & 0.9948 \\
& & & & & \\
& $25{ }^{\circ} \mathrm{C}$ & 0.007 & 0.085 & 0.009 & 0.948 \\
& $30{ }^{\circ} \mathrm{C}$ & 0.002 & 0.049 & 0.003 & 0.9814 \\
& $35{ }^{\circ} \mathrm{C}$ & 0.0005 & 0.023 & 0.0007 & 0.995 \\
& $40{ }^{\circ} \mathrm{C}$ & 0.0005 & 0.023 & 0.0006 & 0.9948 \\
\hline
\end{tabular}

increased. Similar behaviour of $D_{\text {eff }}$ has been reported for okra (Doymaz, 2005), aloe vera (Vega et al., 2007) and onions (Mota, Luciano, Dias, Barroca, \& Guiné, 2010). However, the diffusivity values obtained in the present study are higher than those reported in literature for other vegetables (Chong et al., 2008; Vega et al., 2007). The reason for this could be the higher initial water content of $\mathrm{H}$. elongata allowing greater diffusion coefficients, since the process of diffusion is favored in products with higher proportions of water and lower proportions of solids (Guiné \& Fernandes, 2006). Diffusivity values were then used to fit Eq. (5), to estimate the values of the diffusivity for an infinite temperature, $D_{0}$, and the activation energy for moisture diffusion, $E_{\mathrm{a}}$. The results show a high quality fitting with a $R^{2}$ value of 0.9484 (Fig. 2). The value obtained for the diffusion coefficient at an infinite temperature, $D_{0}$, was $1.87 \mathrm{~m}^{2} / \mathrm{s}$, with activation energy for moisture diffusion, $E_{\mathrm{a}}$, to be $37.2 \mathrm{~kJ} / \mathrm{mol}$. The values of activation energy obtained are in line with those reported for other vegetables (Doymaz, 2005; Mota et al., 2010; Vega et al., 2007).

\subsection{Modelling of drying curves}

Although the drying kinetics was temperature-dependent, the differences in the moisture content decreased as the system reached equilibrium. The drying kinetics data obtained for the four temperatures was fitted to three empirical kinetic models (Table 1). It was observed that $R^{2}$ values (Table 3) ranged from 0.948 to 0.995 for the different models. The fact that drying kinetics was temperature-dependent could be ascertained from the fact that the value of the parameter ' $k$ ' (Table 4 ) increased for all the models as the drying temperature was increased. Fig. 3 shows the predicted and experimental points obtained for the four temperatures with the different models tested: Newton, Henderson-Pabis and Logarithmic. From the results obtained it can be verified that the three models used in this study show a good predicting capacity, and revealed good performance for the temperatures tested, over the entire duration of the drying process. However, Newton model had a

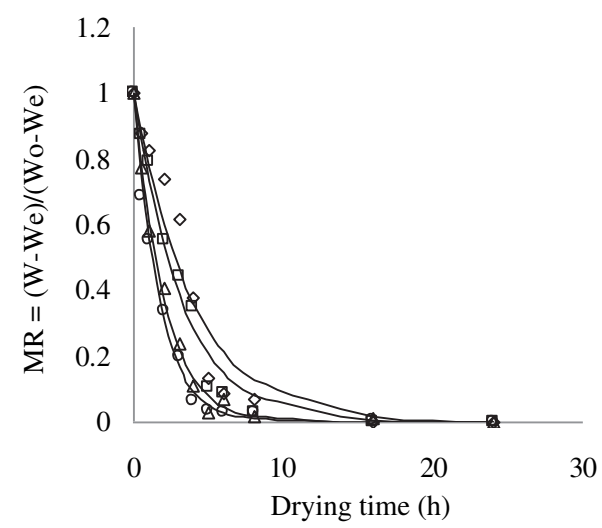

b
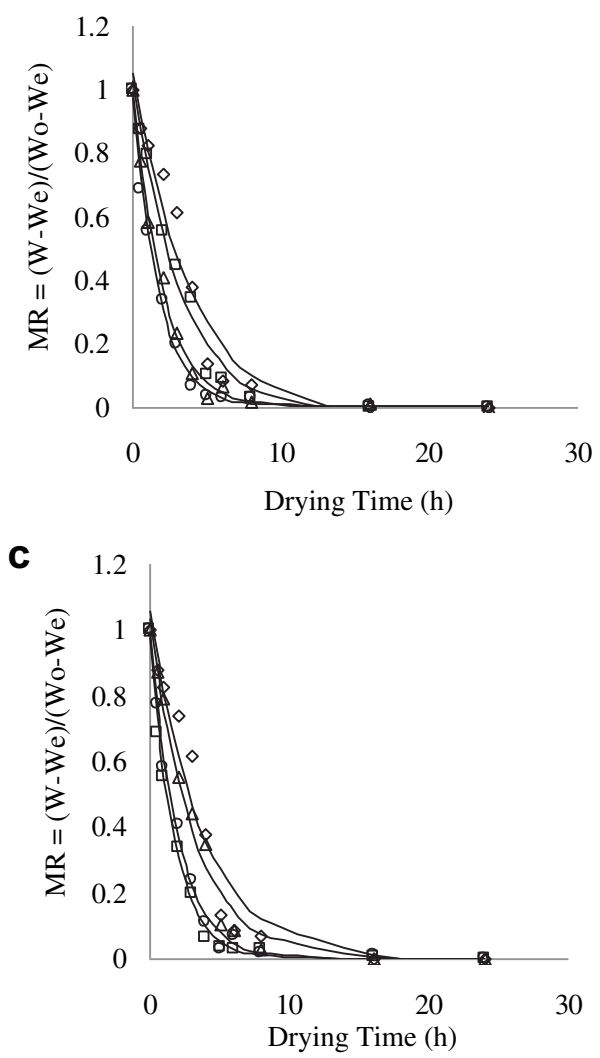

Fig. 3. Experimental and predicted drying curves for (a) Newton; (b) Logarithmic and (c) Henderson-Pabis model for the four temperatures. ( $\diamond: 25^{\circ} \mathrm{C} ; \square: 30^{\circ} \mathrm{C} ; \triangle: 35^{\circ} \mathrm{C}$; $\left.\mathrm{O}: 40{ }^{\circ} \mathrm{C}\right)$.

Table 4

Results of fitting of drying kinetics to the three models (values in curved brackets are the standard error and values in square brackets are $95 \%$ confidence intervals).

\begin{tabular}{|c|c|c|c|c|c|}
\hline & & $25^{\circ} \mathrm{C}$ & $30^{\circ} \mathrm{C}$ & $35^{\circ} \mathrm{C}$ & $40^{\circ} \mathrm{C}$ \\
\hline Newton & $k$ & $0.254( \pm 0.03)[0.192-0.316]$ & $0.313( \pm 0.02)[0.267-0.358]$ & $0.504( \pm 0.02)[0.465-0.542]$ & $0.591( \pm 0.017)[0.541-0.641]$ \\
\hline Logarithmic & $\begin{array}{l}a \\
k \\
c\end{array}$ & $\begin{array}{l}1.103( \pm 0.089)[0.897-1.308] \\
0.247( \pm 0.048)[0.136-0.358] \\
-0.05( \pm 0.07)[-0.215-0.115]\end{array}$ & $\begin{array}{l}1.065( \pm 0.05)[0.951-1.18] \\
0.305( \pm 0.03)[0.226-0.384] \\
-0.03( \pm 0.04)[-0.117-0.053]\end{array}$ & $\begin{array}{l}1.0( \pm 0.025)[0.942-1.058] \\
0.499( \pm 0.032)[0.436-0.573] \\
-0.002( \pm 0.015)[-0.037-0.033]\end{array}$ & $\begin{array}{l}0.976( \pm 0.025)[0.918-1.033] \\
0.581( \pm 0.037)[0.494-0.667] \\
0.003( \pm 0.01)[-0.029-0.035]\end{array}$ \\
\hline $\begin{array}{l}\text { Henderson- } \\
\text { Pabis }\end{array}$ & $\begin{array}{l}a \\
\mathrm{k}\end{array}$ & $\begin{array}{l}1.058( \pm 0.067)[0.905-1.209] \\
0.271( \pm 0.036)[0.189-0.353]\end{array}$ & $\begin{array}{l}1.038( \pm 0.04)[0.95-1.13] \\
0.326( \pm 0.026)[0.267-0.385]\end{array}$ & $\begin{array}{l}0.998( \pm 0.057)[0.95-1.05] \\
0.503( \pm 0.02)[0.45-0.55]\end{array}$ & $\begin{array}{l}0.978( \pm 0.02)[0.93-1.02] \\
0.576( \pm 0.03)[0.515-0.64]\end{array}$ \\
\hline
\end{tabular}

$k, a$ and $c$ are the model parameters. 


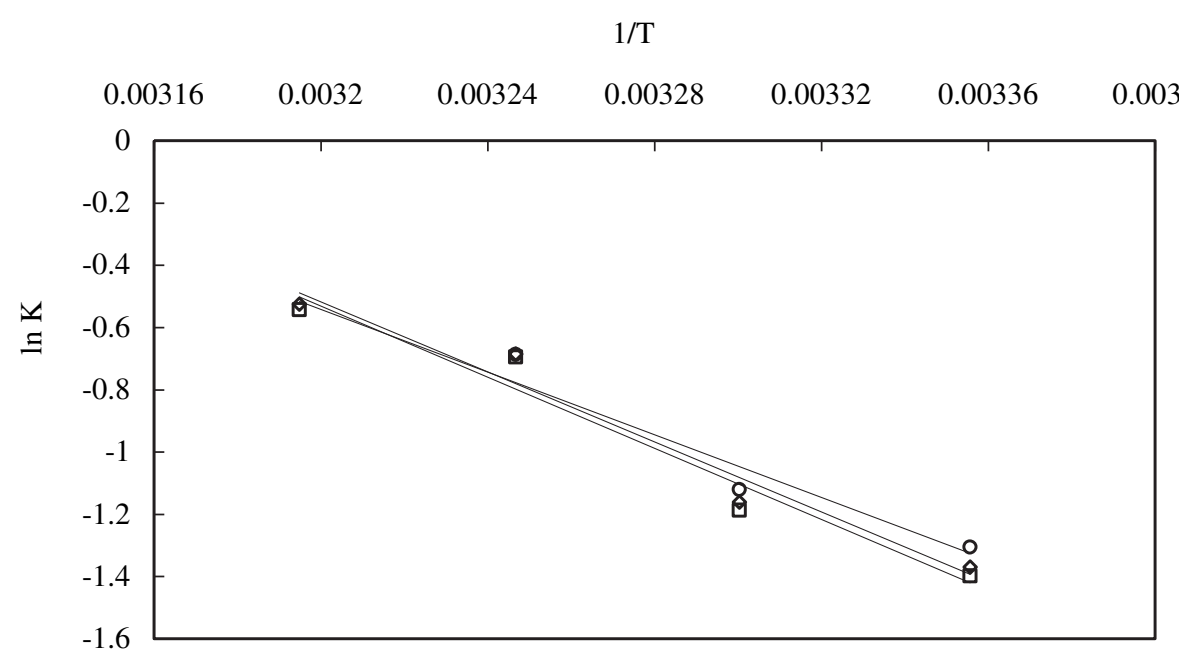

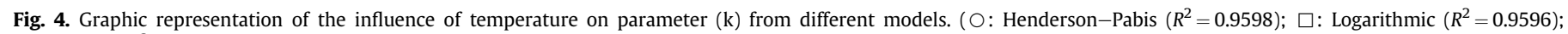
$\diamond:$ Newton $\left.\left(R^{2}=0.9632\right)\right)$.

the lowest $R^{2}$ values among all the three models. The values of the standard error of the parameter ' $k$ ' in the Newton model vary between $3 \%$ and $12 \%$ for all the temperatures studied. The values of standard error for Henderson-Pabis model were within acceptable range for parameter ' $a$ ' $(2 \%-6 \%)$ and ' $k$ ' (5\%-13\%). Regarding the Logarithmic model, the values for the standard errors of parameter ' $a$ ' vary from $3 \%$ to $8 \%$ and ' $k$ ' varies from $6 \%$ to $19 \%$ are within the acceptable range, but the standard errors of the parameters ' $c$ ' for all the temperatures is of the same order of the value itself or greater.

In order to prove the dependence of parameter ' $k$ ' on the drying temperature, the Arrhenius equation was applied, graphically representing $\ln k$ versus $1 / T$ (Simal et al., 2005). Straight lines were obtained with regression coefficients $\left(R^{2}\right)$ higher than 0.98 (Fig. 4 ), from whose slopes activation energies of $46.7,47.4$, and $41.8 \mathrm{~kJ} / \mathrm{mol}$ were obtained for the parameters of Newton, Logarithmic and Henderson-Pabis model, respectively. Based on the similarities between the activation energy of the diffusivity coefficient $(37.16 \mathrm{~kJ} / \mathrm{mol}$ ) and the parameter ' $\mathrm{k}$ ' as obtained above for different models, in addition to the values reported by Senadeera, Bhandari, Young, and Wijesinghe (2003) for other vegetables (12.87-58.15 kJ/ $\mathrm{mol}$ ), the parameter ' $k$ ' can be considered as pseudodiffusivity. The parameter ' $k$ ' represents a pseudodiffusional behaviour of matter transfer as stated in Fick's second law. The ANOVA carried out on the parameters ' $a$ ' of Henderson-Pabis model showed no statistically significant difference $(P>0.05)$ of these parameters as related to temperature, suggesting they probably depend more on the

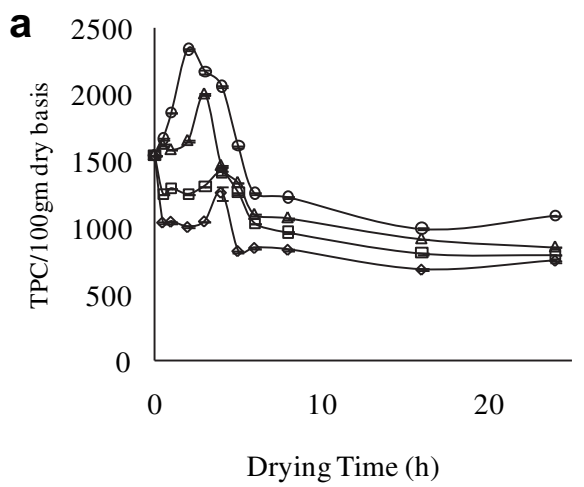

characteristics of the tissue and/or the drying air flow. Vega et al. (2007) also reported similar observations for the parameter ' $a$ ' of HP model.

\subsection{Effect of drying on the phytochemical constituents}

In our previous studies we had reported that methanolic extracts from $H$. elongata have high antioxidant activity (Cox et al., 2009). Processing of any kind will affect content, activity and bioavailability of bioactive compounds. The TPC was monitored for $H$. elongata dried at different temperatures over the entire duration of drying (Fig. 5a). The initial content of total phenol was $1.55 \pm 0.026 \mathrm{~g} \mathrm{GAE} / 100 \mathrm{~g}$ dry seaweed. The content of total phenol was found to be higher than those reported for other common algae such as Laminaria, Undaria, Scytosiphon, Tunbinaria (Chandini et al., 2008; Jiménez-Escrig, Jiménez-Jiménez, Pulido, \& Saura-Calixto, 2001; Kuda, Tsunekawa, Hishi, \& Araki, 2005). Overall drying at different temperatures resulted in a reduction in the TPC; however the content was still higher than the values reported for dried Scytosiphon lomentaria (Kuda et al., 2005). Drying at lower temperatures $\left(25^{\circ} \mathrm{C}\right.$ and $\left.30^{\circ} \mathrm{C}\right)$ resulted in a continuous reduction of TPC (Fig. 5a) although a small increase was seen (at $4 \mathrm{~h}$ ) when the moisture content had reduced by half. But these values were a lot less than that in the fresh seaweed. For higher temperatures $\left(35^{\circ} \mathrm{C}\right.$ and $40^{\circ} \mathrm{C}$ ) an increase in the TPC content was seen for the first $2 \mathrm{~h}$ after which it started decreasing (Fig. 5a). Maximum increase of $41 \%$ in the TPC was seen after drying at $40{ }^{\circ} \mathrm{C}$ for $2 \mathrm{~h}$. Since identical

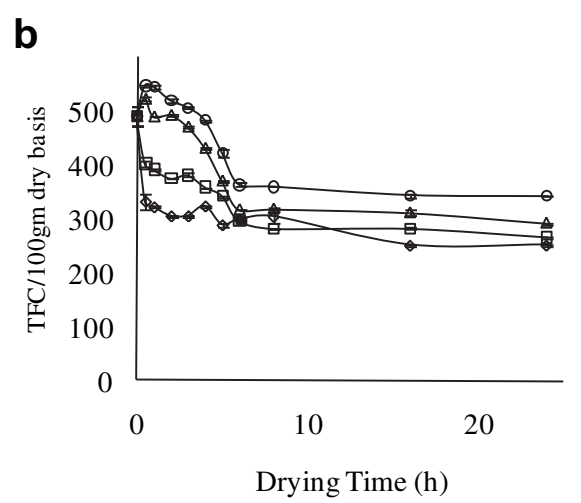

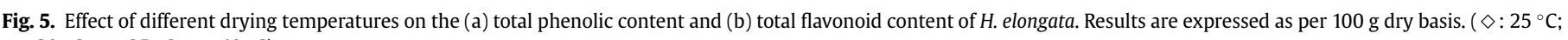
$\left.\square: 30^{\circ} \mathrm{C} ; \triangle: 35^{\circ} \mathrm{C} ; \Delta: 40^{\circ} \mathrm{C}\right)$. 
amounts of sample were taken for fresh and dried seaweeds, there was no influence of residual moisture on the antioxidant capacity or TPC of the samples. This increase could be related to the developmental changes and wound-like response due to drying. Dixon and Paiva (1995) reported that plants respond to wounding with increase in phenolic compounds involved in the repair of wound damage. However, at the end of the $24 \mathrm{~h}$ drying period a significant reduction $(29-51 \%)$ in the TPC was seen for $H$. elongata dried at different temperatures $(P<0.5)$. Maximum reduction of $51 \%$ in the TPC was seen in $H$. elongata dried at $25^{\circ} \mathrm{C}$ whereas a reduction of only $29 \%$ was seen when drying was done at $40^{\circ} \mathrm{C}$ as compared to fresh seaweed. A probable reason for this could be the long drying time of seaweeds at $25^{\circ} \mathrm{C}$ to achieve a similar equilibrium moisture content as compared to when drying at $40^{\circ} \mathrm{C}$. Jiménez-Escrig et al. (2001) reported a 98\% reduction in the TPC content on brown seaweed Fucus dried at $50{ }^{\circ} \mathrm{C}$ for $48 \mathrm{~h}$. Garau et al. (2007) reported that longer drying times resulted in a reduction of TPC for orange by-products. Also, the lower drying temperatures used in the present study probably did not inactivate the oxidative enzymes completely, which may have in turn resulted in some oxidation of the phenolic substances and resulted in a relatively lower phenolic content. Decrease in TPC during drying can also be attributed to the binding of polyphenols with other compounds (proteins) or the alterations in the chemical structure of polyphenols which cannot be extracted or determined by available methods (Martín-Cabrejas et al., 2009; Qu, Pan, \& Ma, 2010).

Fig. 5b shows the variation in the TFC for the four different temperatures studied. The TFC in the fresh seaweeds was $0.49 \mathrm{~g} \pm 0.019 \mathrm{QE} / 100 \mathrm{~g}$ dry seaweed. TPC reduced continuously for the lower temperatures but at higher temperatures it increased initially and then decreased. Drying led to a reduction in the TFC as well, although the \% reduction declined as the drying temperature increased. A percentage reduction of $49 \%$ and $30 \%$ was seen at $25{ }^{\circ} \mathrm{C}$ and $40^{\circ} \mathrm{C}$, respectively.

The antioxidant capacity of fresh and dried $H$. elongata was determined by the DPPH radical scavenging assay. Minimum $\mathrm{EC}_{50}$ value was seen for fresh seaweeds $(10 \mu \mathrm{g} / \mathrm{ml})$. Reduction in TPC values at various drying temperatures was accompanied by a reduction in the antioxidant potential as well. Drying resulted in significant decrease $(P<0.05)$ in the antioxidant activity exhibited by the reduction in DPPH free radical scavenging activity, i.e. higher $\mathrm{EC}_{50}$ of $25\left(25^{\circ} \mathrm{C}\right.$ and $\left.30^{\circ} \mathrm{C}\right)$ and $50 \mu \mathrm{g} / \mathrm{ml}\left(35^{\circ} \mathrm{C}\right.$ and $\left.40^{\circ} \mathrm{C}\right)$ as compared to an $\mathrm{EC}_{50}$ of $10 \mu \mathrm{g} / \mathrm{ml}$ for fresh samples.

Li, Smith, and Hossain (2006) had reported that a combination of high drying temperatures and long drying times might destroy some of the phenol compounds. In addition, all the plant cell components adhere together in the absence of water, and possibly making the extraction with solvent more difficult; as a result, the overall recoveries might be lower than expected (Li et al., 2006). Sun drying and subsequent storage of algae have been reported to cause a reduction in the levels of labile antioxidants such as L-ascorbate and GSH (Burritt, Larkindale, \& Hurd, 2002; JiménezEscrig et al., 2001). The drying process would generally result in a depletion of naturally occurring antioxidants in raw materials from plants. Intense and/or prolonged thermal treatment may be responsible for a significant loss of natural antioxidants, as most of these compounds are relatively unstable (Lim \& Murtijaya, 2007).

\section{Conclusion}

This study showed that the drying kinetics of seaweeds can be accurately predicted using the empirical models of Newton, Logarithmic or Henderson-Pabis model. The moisture transfer can be described by diffusion and the temperature dependence of the effective moisture diffusivities was shown to follow an Arrhenius relationship. Drying reduced the phytochemical constituents in the seaweed. A reduction of $29 \%$ in the TPC and $30 \%$ in the TFC was seen when $\mathrm{H}$. elongata was dried at $40^{\circ} \mathrm{C}$. However, an important increase of $41 \%$ in the TPC was nonetheless observed when the seaweed was dried up to $50 \%$ moisture content. This would mean that the semi-dried form of seaweeds which is even more nutritious than the raw state could be used for the development of health promoting seaweed based products. However, the results also showed that processing of $H$. elongata by drying resulted in a substantial reduction of the phytochemicals which leads to the fact that new research into protecting antioxidant properties of seaweeds upon processing would be needed.

\section{Acknowledgement}

The authors acknowledge funding from the Dublin Institute of Technology under the ABBEST Programme. The authors would also like to thank Denis Benson, Noel Grace and Tony Hutchinson for their technical support.

\section{References}

Athukorala, Y., Kim, K.-N., \& Jeon, Y. J. (2006). Antiproliferative and antioxidant properties of an enzymatic hydrolysate from brown alga, Ecklonia cava. Food and Chemical Toxicology, 44, 1065-1074.

Burritt, D. J., Larkindale, J., \& Hurd, C. L. (2002). Antioxidant metabolism in the intertidal red seaweed Stictosiphonia arbuscula following desiccation. Planta, 215, 829-838.

Capecka, E., Mareczeek, A., \& Leja, M. (2005). Antioxidant activity of fresh and dry herbs of some Lamiaciae species. Food Chemistry, 93, 223-226.

Chan, C. C. J., Cheung, P. C. K., \& Ang, P. O., Jr. (1997). Comparative studies on the effect of three drying methods on the nutritional composition of seaweed Sargassum hemiphyllum (Turn.) C. Ag. Journal of Agricultural and Food Chemistry, 45, 3056-3059.

Chandini, S. K., Ganesan, P., \& Bhaskar, N. (2008). In vitro antioxidant activities of three selected brown seaweeds of India. Food Chemistry, 107, 707-713.

Chong, C. H., Law, C. L., Cloke, M., Hii, C. L., Abdullah, L. C., \& Daud, W. R. W. (2008). Drying kinetics and product quality of dried Chempedak. Journal of Food Engineering, 88, 522-527.

Coulson, J. M., Richardson, J. F., Backhurst, J. R., \& Harker, J. H. (1987). Chemical engineering, unit operation (3rd ed.). UK: Pergamon Press Ltd. pp. 717-718.

Cox, S., Abu-Ghannam, N., \& Gupta, S. (2009). An assessment of the antioxidant and antimicrobial activity of six species of edible Irish seaweeds. International Food Research Journal, 17, 205-220.

Dawczynski, C., Schubert, R., \& Jahreis, G. (2007). Amino acids, fatty acids, and dietary fibre in edible seaweed products. Food Chemistry, 103, 891-899.

Dixon, R. A., \& Paiva, N. L. (1995). Stress-induced phenylpropanoid metabolism. Plant Cell, 7, 1085-1097.

Doymaz, I. (2005). Drying characteristics and kinetics of okra. Journal of Food Engineering, 9, 275-279.

Garau, M. C., Simal, S., Rosselló, C., \& Femenia, A. (2007). Effect of air-drying temperature on physico-chemical properties of dietary fibre and antioxidan capacity of orange (Citrus aurantium v. Canoneta) by-products. Food Chemistry, 104, 1014-1024.

Guiné, R. P. F., \& Fernandes, R. M. C. (2006). Analysis of the drying kinetics of chestnuts. Journal of Food Engineering, 76, 460-467.

Gupta, S., Rajauria, G., \& Abu-Ghannam, N. (2010). Study of the microbial diversity and antimicrobial properties of Irish edible brown seaweeds. International Journal of Food Science and Technology, 45, 482-489.

http://www.cleanerproduction.ie/download/phase2/arramara.pdf (accessed 07.06.10).

Jiménez-Escrig, A., Jiménez-Jiménez, I., Pulido, R., \& Saura-Calixto, F. (2001). Antioxidant activity of fresh and processed edible seaweeds. Journal of Science of Food and Agriculture, 81, 530-534.

Kuda, T., Tsunekawa, M., Hishi, T., \& Araki, Y. (2005). Antioxidant properties of dried 'kayamo-nori', a brown alga Scytosiphon lomentaria (Scytosiphonales, Phaeophyceae). Food Chemistry, 89, 617-622.

Li, B. B., Smith, B., \& Hossain, Md. M. (2006). Extraction of phenolics from citrus peels. I. Solvent extraction method. Separation and Purification Technology, 48, $182-188$

Lim, Y. Y., \& Murtijaya, J. (2007). Antioxidant properties of Phyllanthus amarus extracts as affected by different drying methods. LWT Food Science and Technology, 40, 1664-1669.

Liu, S. C., Lin, J. T., Wang, C. K., Chen, H. Y., \& Yang, D. J. (2009). Antioxidant properties of various solvent extracts from lychee (Litchi chinenesis Sonn.) flowers. Food Chemistry, 114, 577-581.

Martín-Cabrejas, M. A., Aguilera, Y., Pedrosa, M., Cuadrado, C., Hernández, T., Díaz, S., et al. (2009). The impact of dehydration process on antinutrients 
and protein digestibility of some legume flours. Food Chemistry, 114, 1063-1068.

Matsukawa, R., Dubinsky, Z., Kishimoto, E., Masaki, K., Masuda, Y., \& Takeuchi, T. (1997). A comparison of screening methods for antioxidant activity in seaweeds. Journal of Applied Phycology, 9, 29-35.

Miranda, M., Maureira, H., Rodríguez, K., \& Vega-Gálvez, A. (2009). Influence of temperature on the drying kinetics, physicochemical properties, and antioxidant capacity of Aloe Vera (Aloe Barbadensis Miller) gel. Journal of Food Engineering, 91, 297-304.

Mota, C. L., Luciano, C., Dias, A., Barroca, M. J., \& Guiné, R. P. F. (2010). Convective drying of onion: kinetics and nutritional evaluation. Food and Bioproducts Processing, 88, 115-123.

Nicoli, M. C., Anese, M., \& Parpinel, M. (1999). Influence of processing on the antioxidant properties of fruits and vegetables. Trends in Food Science and Technology, 10, 94-100.

Qu, W., Pan, Z., \& Ma, H. (2010). Extraction modeling and activities of antioxidants from pomegranate marc. Journal of Food Engineering, 99, 16-23.
Senadeera, W., Bhandari, B. R., Young, G., \& Wijesinghe, B. (2003). Influence of shapes of selected vegetable material on drying kinetics during fluidized bed drying. Journal of Food Engineering, 58, 277-283.

Simal, S., Femenía, A., Garau, M. C., \& Roselló, C. (2005). Use of exponential, Page's and diffusional models to simulate the drying kinetics of kiwi fruit. Journal of Food Engineering, 66, 323-328.

Taga, M. S., Miller, E. E., \& Pratt, D. E. (1984). Chia seeds as a source of natural lipid antioxidants. Journal of the American Oil Chemists Society, 61, 928-931.

Vega, A., Uribe, E., Lemus, R., \& Miranda, M. (2007). Hot-air drying characteristics of Aloe vera (Aloe barbadensis Miller) and influence of temperature on kinetic parameters. LWT - Food Science and Technology, 40, 1698-1707.

Wong, K., \& Cheung, P. C. (2001). Influence of drying treatment on three Sargassum species 2. Protein extractability, in vitro protein digestibility and amino acid profile of protein concentrates. Journal of Applied Phycology, 13, 51-58.

Yen, G. C., \& Chen, H. Y. (1995). Antioxidant activity of various tea extracts in relation to their antimutagenicity. Journal of Agricultural and Food Chemistry, 43, 27-32. 